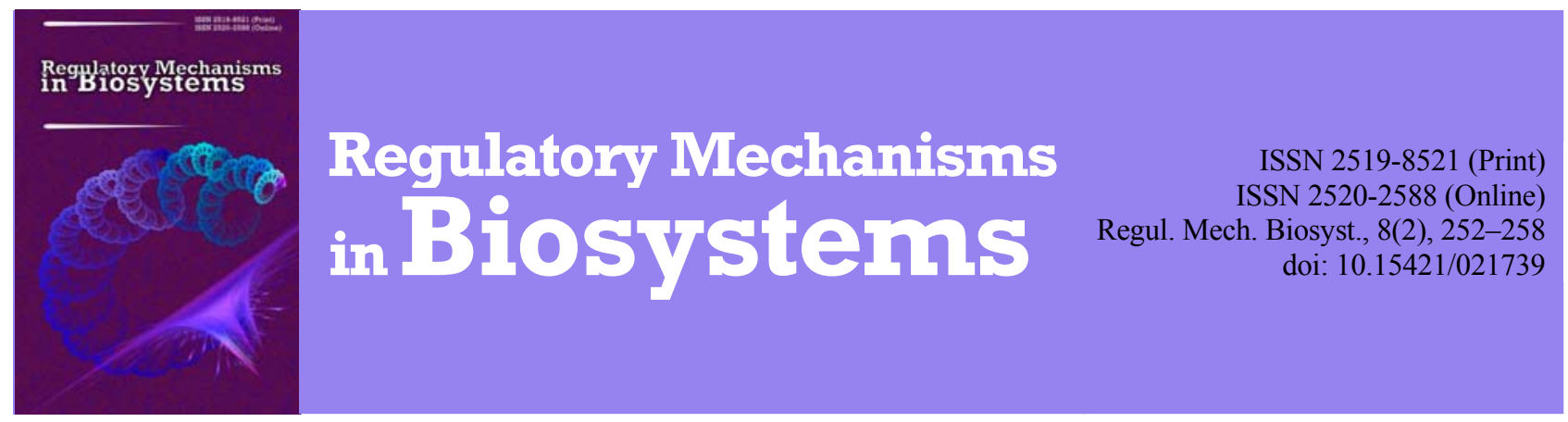

\title{
Correction of vaginal dysbiosis in mice caused by a film-forming strain Staphylococcus aureus, using bacteriophages and probiotics
}

\author{
E. S. Vorobey, O. S. Voronkova, A. I. Vinnikov \\ Oles Honchar Dnipro National University, Dnipro, Ukraine
}

Article info

Received 28.03.2017

Received in revised form

27.04.2017

Accepted 29.04.2017

Oles Honchar Dnipro National University

Gagarin Ave., 72 ,

Dnipro, 49010, Ukraine.

Tel.: +38-056-760-85-14.

E-mail:

Elizaveta.vorobey89@gmail.com
Vorobey, E. S., Voronkova, O. S., \& Vinnikov, A. I. (2017). Correction of vaginal dysbiosis in mice caused by a filmforming strain Staphylococcus aureus, using bacteriophages and probiotics. Regulatory Mechanisms in Biosystems, 8(2), 252-258. doi:10.15421/021739

The complex use of bacteriophages and probiotics is a promising trend in improving prevention and treatment of gynecological lesions. Our study of their influence on the microflora was performed on the model of vaginal dysbiosis of white laboratory mice induced by introduction of a filmforming strain of Staphylococcus aureus. For correction of dysbiosis, staphylococcal bacteriophage liquid, piobacteriophage polyvalent, intesti-bacteriophage liquid and probiotic "Vahilak" were used. For the identification of the microflora of the reproductive tract, samples of biological material from the vagina were obtained by sterile cotton swab and plated on nutrient media to determine the nature and extent of growth of the cultures. The maximal effect was found to occur with the correctional complex "bacteriophage staphylococcal liquid - vahilak" that led to decrease of total microbial number to $4.77 \times 10^{4} \mathrm{CFU} / \mathrm{ml}$ and to the restoration of the ratio of aerobic to anaerobic bacteria $1: 52$ when indicators of the norm were $4,69 \times 10^{4} \mathrm{CFU} / \mathrm{ml}$ and 1 : 52. In this case, 24 hours after the last injection of the preparations the amount of microaerophilic and anaerobic lactobacilli had increased by 20.8 and 2.1 times respectively. The frequency of isolation of microaerophilic lactobacilli increased to $100 \%$, and anaerobic - up to $70 \%$. Also the number of staphylococci, streptococci, enterococci, bacilli and enterobacteria decreased by $30.1,1.1,1.5,2.2$ and 11.8 times respectively. Also, there was a decrease in the detection rate of enterococci, micrococci and enterobacteria by $10 \%$ and bacilli by $20 \%$ compared to the control dysbiosis. The number of anaerobic bacteria also underwent significant changes. Thus, the number of fusobacteria decreased by 33.2 times, peptococci - 2.3, peptostreptococci - 6.6 and Bacteroides - 7.9 times, which is almost consistent with indicators of the norm. In addition, the frequency of detection of peptostreptococci decreased by $10 \%$. Therefore, it can be concluded that medical bacteriophages are active against lesions caused by able to film-forming staphylococci, in vivo, so they are appropriate to use in medical practice both independently and in combination with other agents.

Keywords: reproductive tract; biofilm; staphylococci; phage; vahilak; microflora

\section{Корекція дисбіозу піхви мишей, викликаного плівкотвірним штамом Staphylococcus aureus, за допомогою бактеріофагів і пробіотиків}

\author{
Є. С. Воробєй, О. С. Воронкова, А. І. Вінніков \\ Дніпровський національний університет імені Олеся Гончара, Дніпро, Украӥна
}

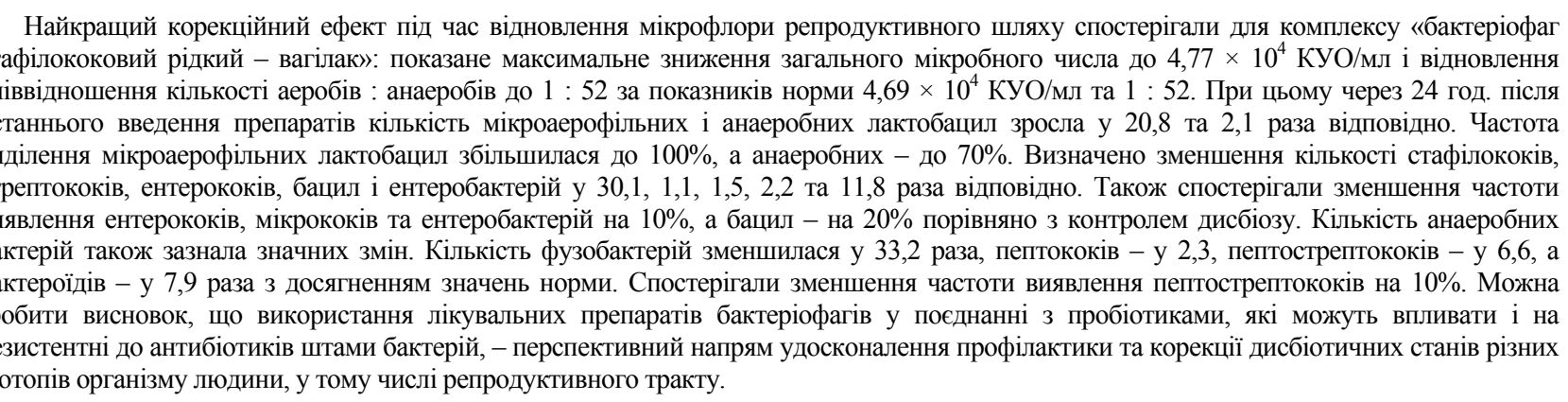

Ключові слова: репродуктивний тракт; біоплівка; стафілокок; фаг; вагілак; мікрофлора 


\section{Вступ}

За фізіологічної норми жіночий організм контактує з тисячами видів мікробів, перебуваючи 3 ними в симбіотичних відносинах. За впливу ендогенних і екзогенних факторів відбувається постійна зміна мікробіоти вагінального біотопу, що спричиняє порушення складу нормальної мікрофлори. Зменшення кількості лактобацил і збільшення анаеробних представників мікрофлори трактується як дисбіоз (Algburi et al., 2015; Machado and Cerca, 2015). Дисбіоз піхви можна розглядати як початковий етап формування інфекційного процесу з розвитком запальної реакції локального або системного характеру.

Значну небезпеку в гінекології (у зв'язку зі швидким набуттям антибіотикорезистентності та підвищенням патогенного потенціалу) являють аеробні представники факультативної та транзиторної флори вагінального біоценозу, зокрема, бактерії роду Staphylococcus. За глибоких дисбіотичних розладів на тлі масивної антибіотикотерапії золотистий стафілокок найчастіше стає збудником ендогенних інфекцій практично будь-якої локалізації, як самостійно, так і в асоціації з іншими потенційними патогенами. Збільшення кількості стафілококів у складі мікробіоти піхви - головний фактор, що зумовлює пригнічення розвитку представників нормальної мікрофлори цього біотопу, зокрема лактобацил.

Відповідно до сучасних даних, ключову роль у патогенезі дисбактеріозу репродуктивного тракту відіграє утворення бактеріями біоплівок - стійких бактеріальних асоціацій, що являють собою універсальний механізм формування резистентності бактерій до різних лікувальних препаратів (Нoiby, 2011; Swidsinski et al., 2013; Machado and Cerca, 2015; Muzny and Schwebke, 2015). Стафілококові біоплівки на слизовій оболонці піхви блокують запальну відповідь, знижують активність імуноцитів, що дозволяє бактеріям досягати високих концентрацій (Verstraelen and Swidsinski, 2013), створюють усталені патологічні біоценози піхви. Вони зберігають життєздатність мікроорганізмів за концентрацій перекису водню та молочної кислоти у 4-8 разів вищих, ніж потрібно для пригнічення окремих бактерій поза плівками (Berezovskaya et al., 2013). Саме стафілококи найчастіше виступають у ролі ініціаторів біоплівкового процесу, готуючи грунт для інших мікробів. Отже, саме тому вони обрані для створення експериментальної моделі дисбіозу вагінального біотопу.

Традиційна антимікробна терапія не усуває основної причини розвитку патології - дисбіотичних розладів у вагінальній екосистемі. Існуючі методи медикаментозної терапії уражень статевої системи із застосуванням етіотропних антибактеріальних препаратів викликають синдром імунної недостатності, що характеризується порушенням гуморального та клітинного імунітету, синтезу компонентів комплементу, відсутністю або зниженням активності цитотоксичних лімфоцитів і макрофагів. Результати розвитку цього синдрому та утворення стафілококами біоплівок - тривала персистенція збудника, часті рецедиви захворювання, можливості подальших заражень інфекційними агентами іншої природи, оскільки відновлення імунного статусу та нормалізація мікробіоценозу відбувається в недостатньому обсязі та темпі або не відбувається зовсім (Römling and Balsalobre, 2012). Крім того, антибіотики знижують колонізаційну резистентність піхви, збільшують проникність слизової оболонки, сприяючи тим самим проникненню умовно-патогенних мікроорганізмів у кров'яне русло, внутрішні органи та розвитку вторинного вогнища інфекції та алергізації організму.

Отже, терапія антибактеріальними препаратами викликає дестабілізацію вагінальної екосистеми, внаслідок чого відбувається різке зниження кількісних і якісних характеристик нормальної синергідної мікрофлори, збільшення $\mathrm{pH}$ вагінального секрету, тобто створюються умови для масового розмноження умовно-патогенної мікрофлори (Machado et al., 2016). Тому актуальності набуває пошук нових методів і альтернативних антибіотикам препаратів для корекції дисбіозу репродуктивного тракту. Найефективніші та перспективні в цьому сенсі лікувальні препарати бактеріофагів. Згідно з результатами сучасних досліджень, препарати бактеріофагів чинять значний ефект у більшості випадків, нерідко стаючи засобом вибору (Abedon, 2016; Motlagh et al., 2016).

Стафілококові бактеріофаги, дія яких спрямована безпосередньо на клітини стафілококів, не впливають на пул вагінальних лактобацил, що відіграє головну роль у виборі антимікробних засобів для корекції дисбіотичних станів (Algburi et al., 2015). Вони здатні проникати всередину бактеріальних біоплівок i уражати клітини в їх складі (Deghorain and Van Melderen, 2012; Lungren et al., 2013; Yilmaz et al., 2013; Alves et al., 2014). Для цього фаги виробляють деполімерази, здатні руйнувати матрикс біоплівок (Abedon, 2015; Chan and Abedon, 2015). Окрім літичної дії, бактеріофаги стимулюють фактори специфічного та неспецифічного імунного захисту: активують фагоцитоз, активність нейтрофілів, підвищують рівень Т-лімфоцитів, що попереджає хронізацію запального процесу та його рецидивування (Stepanova and Gevorkyan, 2015).

Пробіотики, у свою чергу, знижують ризик розвитку гастроінтестинальних розладів, викликаних антибіотикотерапією, ініціюють відновлення мікробіоценозу та інших порушених фізіологічних процесів в організмі. Механізм впливу пробіотиків на слизову піхви має багатофакторний характер і зумовлений продукцією молочної кислоти, бактерицидних речовин (антимікробних пептидів або бактеріоцинів) і перекису водню, модифікацією імунної відповіді (синтез IgA і протизапальних цитокінів), синтезом специфічних молекул, здатних знижувати вірулентність патогенів, та низкою інших факторів (Borges et al., 2014).

Отже, окреме використання лікувальних бактеріофагів та пробіотиків, які можуть впливати на резистентні до антибіотиків штами бактерій, стало перспективним напрямом в удосконаленні профілактики та лікуванні уражень, у тому числі репродуктивного тракту.

Тому мета цієї статті - розробити схему корекції дисбіозів за участі пробіотиків і фагів на моделі експериментального дисбіозу піхви білих лабораторних мишей, створеній шляхом інтравагінального уведення суспензій клітин плівкотвірного штаму $S$. aureus.

\section{Матеріал і методи досліджень}

Дослідження проводили на білих лабораторних мишах із віварію Дніпровського національного університету імені Олеся Гончара. Відбирали самиць віком 18-24 тижні та вагою 1822 г. Тварин розподіляли на групи випадковим чином залежно від потреб експерименту, початкова чисельність кожної групи становила 9-10 особин.

Для визначення складу мікрофлори репродуктивного тракту мишей біологічний матеріал відбирали 3 піхви стерильними ватними тампонами. Із тампонів проводили змив у 1 мл стерильного розчину натрію хлориду $(0,5 \%)$ та висівали отриману суспензію по 50 мкл на живильні середовища. За необхідності культивування проводили в ексикаторі за зниженого парціального тиску $\mathrm{O}_{2}$. Культивування анаеробів проводили в анаеростаті, заповненому інертним газом.

Ідентифікацію бактерій проводили 3 використанням стандартних методик (Order of MoH USSR №535, 1985). Культури ідентифікували за результатами вивчення морфологічних, тинкторіальних та фізіолого-біохімічних ознак.

Для створення дисбіозу дослідним тваринам інтравагінально вводили 50 мкл суспензії добової культури плівкотвірного штаму стафілококу, що містила $1 \times 10^{9}$ КУО/мл. Контрольний висів проводили через 24 год. після зараження та через 10 діб, визначаючи зміни складу мікрофлори. Загальна кількість мишей із дисбіозом становила 68 особин.

Для корекції дисбіозу використовували лікувальні препарати: бактеріофаг стафілококовий рідкий, піобактеріофаг полі- 
валентний та інтесті-бактеріофаг рідкий (НПО «Микроген», РФ) і пробіотичний препарат «Вагілак» (Ядран, Хорватія). Препарати вводили інтравагінально по 50 мкл протягом 10 діб. Контрольне висівання проводили через добу після останнього введення препарату і ще через 10 та 20 діб, відстежуючи динаміку змін.

Всі досліди на тваринах проводили відповідно до норм, установлених Законом України №3447-IV «Про захист тварин від жорстокого поводження» та прийнятих у Європейській конвенції із захисту хребетних тварин, що використовуються для експериментальних цілей (Law of Ukraine №3447-IV, 2006; European Convention for the Protection of Vertebrate Animals used for Experimental and Other Scientific Purposes, 1986).

Статистичну обробку отриманих результатів здійснювали, розраховуючи середне значення та стандартну похибку з використанням програми Origin Lab Pro 7.0 (OriginLab Corporation, USA). Достовірними вважали відмінності за $\mathrm{P}<0,05$.

\section{Результати}

Перед створенням експериментальної моделі дисбіозу піхви мишей, викликаного введенням плівкотвірного штаму золотистого стафілокока, провели вивчення складу індигенної мікробіоти здорових тварин для подальшого порівняння з ним показників дисбіозу.

Серед здорових мишей (контрольна група з 10 особин) виявляли мікроаерофільних Lactobacillus, Staphylococcus i Streptococcus у 100,0\% дослідних тварин. Частота виявлення Enterococcus становила $30,0 \%$, Micrococcus - 10,0\%, Bacillus - 10,0\%, представників родини Enterobacteriaceae - $10,0 \%$ та роду Gardnerella - 30,0\%. Серед анаеробних бактерій Fusobacterium і Bacteroides виявляли у 100\% досліджених тварин, Peptococcus - y 70,0\%, Peptostreptococcus - у 60,0\%, анаеробні Lactobacillus - у 70,0\%.

Що стосується кількісних показників вмісту бактерій у складі нормофлори піхви мишей, серед факультативних анаеробів домінувати стали представники роду Streptococcus i мікроаерофільні Lactobacillus (2,60 \pm 1,28 та 2,29 $\pm 1,46 \operatorname{lgKУО/мл~}$ відповідно). Кількість бактерій родів Staphylococcus, Enterococ- cus, Micrococcus i Gardnerella коливалися на приблизно однаковому рівні та становила 1,85 $\pm 1,17 \operatorname{lgKУО/мл~для~стафілококів,~}$ $1,80 \pm 1,18 \lg$ УО/мл для ентерококів, $1,78 \operatorname{lgКУО/мл~для~мікро-~}$ коків та 1,82 $\pm 1,18$ - для гарднерел. Кількість бактерій роду $B a$ cillus і представників родини Enterobacteriaceae сягала мінімального рівня (1,0 та 1,3 $\lg$ УО/мл відповідно). Кількість облігатноанаеробних бактерій була значно більшою. Так, кількість бактерій роду Fusobacterium склала 3,16 $\pm 2,38$, роду Peptococcus $-4,09 \pm$ 3,30, роду Peptostreptococcus - 3,90 $\pm 2,53$, роду Bacteroides $-3,71 \pm$ 2,45 , а анаеробних Lactobacillus - 4,28 $\pm 3,34 \operatorname{lgKУО/мл.~}$

У складі мікрофлори піхви мишей переважали облігатні анаероби. Відношення кількості аеробів до анаеробів складало $1: 52$. Загальне мікробне число становило $4,69 \times 10^{4} \mathrm{KУО/мл.}$

На наступному етапі нашого дослідження проводили моделювання дисбіозу піхви мишей шляхом інтравагінального введення плівкотвірного штаму $S$. aureus. Зміни складу мікрофлори визначали через 24 год. та 10 діб після введення.

Через 24 години після зараження встановили, що частота виявлення мікроаерофільних Lactobacillus знизилася до 64,7\%, тоді як представники родів Enterococcus, Micrococcus, Bacillus, Gardnerella та представників родини Enterobacteriaceae виявляли 3 більшою частотою $(39,7 \%, 23,5 \%, 23,5 \%, 25,0 \%$ та $20,6 \%$ відповідно). Серед анаеробних бактерій також зареєстровано зміни частоти виявлення: бактерії роду Peptococcus виявляли у 75,0\% досліджених тварин, роду Peptostreptococcus - у 70,6\%, а анаеробні Lactobacillus - у 48,5\% порівняно 3 контролем норми мікрофлори піхви мишей.

Змінилася також кількість виявлених бактерій майже всіх зазначених мікроорганізмів (табл. 1). Так, кількість Lactobacillus, як мікроаерофільних так і анаеробних, знизилася в 3,8 та 4,0 раза порівняно із контролем відповідно. Кількість Staphylococcus збільшилася у 27,1 раза, Bacillus - у 7,3, представників родини Enterobacteriaceae - у 14,0, Fusobacterium - у 41,2, Peptococcus - y 4,2, Peptostreptococcus - у 6,3 та Bacteroides - y 12,5 раза. Як і у контролі, переважали облігатні анаероби. Відношення кількості аеробів до анаеробів складало $1: 77$. Загальне мікробне число зросло у 5,2 раза та становило $2,34 \times 10^{5} \mathrm{KУО/мл.}$

\section{Таблиця 1}

Мікрофлора піхви під час моделювання дисбіозу шляхом уведення клітин плівкотвірного штаму S. aureus через 1 добу та 10 діб після введення $(\operatorname{lgKУO/мЛ,~х~} \pm$ SD)

\begin{tabular}{|c|c|c|c|c|c|c|c|c|c|c|c|c|c|}
\hline \multirow[b]{3}{*}{ Групи тварин } & \multicolumn{13}{|c|}{ Мікроорганізми } \\
\hline & \multirow[b]{2}{*}{ 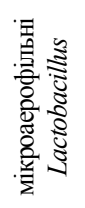 } & \multicolumn{7}{|c|}{ факультативно-анаеробні та аеробні бактерії } & \multicolumn{5}{|c|}{ облігатно-анаеробні бактерії } \\
\hline & & 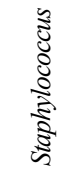 & 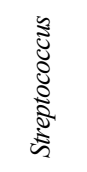 & 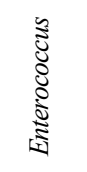 & 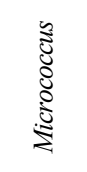 & 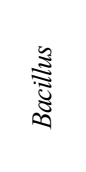 & 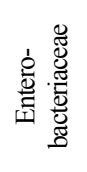 & 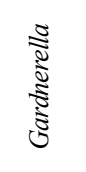 & 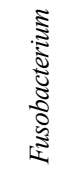 & 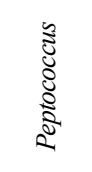 & 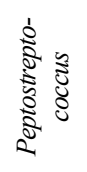 & 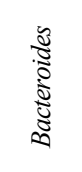 & 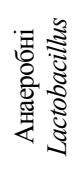 \\
\hline $\begin{array}{l}\text { Контроль норми, } \\
\mathrm{n}=10\end{array}$ & $\begin{array}{c}2,29 \pm \\
1,46\end{array}$ & $\begin{array}{c}1,85 \pm \\
1,17\end{array}$ & $\begin{array}{c}2,60 \pm \\
1,28\end{array}$ & $\begin{array}{c}1,80 \pm \\
1,18\end{array}$ & $1,78^{\circ}$ & $1,00^{\circ}$ & $1,30^{\circ}$ & $\begin{array}{c}1,82 \pm \\
1,18\end{array}$ & $\begin{array}{c}3,16 \pm \\
2,38\end{array}$ & $\begin{array}{c}4,09 \pm \\
3,30\end{array}$ & $\begin{array}{c}3,90 \pm \\
2,53\end{array}$ & $\begin{array}{l}3,71 \pm \\
2,45\end{array}$ & $\begin{array}{c}4,28 \pm \\
3,34\end{array}$ \\
\hline $\begin{array}{l}\text { Дисбіоз, через } 1 \text { добу } \\
n=68\end{array}$ & $\begin{array}{l}1,71 \pm \\
1,10^{*}\end{array}$ & $\begin{array}{l}3,28 \pm \\
2,49 *\end{array}$ & $\begin{array}{c}2,67 \pm \\
1,68\end{array}$ & $\begin{array}{c}2,01 \pm \\
1,28\end{array}$ & $\begin{array}{c}1,74 \pm \\
1,01\end{array}$ & $\begin{array}{l}1,86 \pm \\
1,05^{*}\end{array}$ & $\begin{array}{c}2,45 \pm \\
1,36^{*}\end{array}$ & $\begin{array}{l}1,92 \pm \\
1,13^{*}\end{array}$ & $\begin{array}{l}4,78 \pm \\
3,45^{*}\end{array}$ & $\begin{array}{l}4,71 \pm \\
3,41 *\end{array}$ & $\begin{array}{l}4,70 \pm \\
3,43^{*}\end{array}$ & $\begin{array}{l}4,81 \pm \\
3,45^{*}\end{array}$ & $\begin{array}{l}3,68 \pm \\
2,45^{*}\end{array}$ \\
\hline $\begin{array}{l}\text { Дисбіоз, через } 10 \text { діб } \\
\mathrm{n}=68\end{array}$ & $\begin{array}{l}1,07 \pm \\
0,58^{*}\end{array}$ & $\begin{array}{l}3,36 \pm \\
2,36^{*}\end{array}$ & $\begin{array}{c}2,66 \pm \\
1,46\end{array}$ & $\begin{array}{c}2,02 \pm \\
1,26\end{array}$ & $\begin{array}{c}1,74 \pm \\
1,03\end{array}$ & $\begin{array}{l}1,83 \pm \\
1,16^{*}\end{array}$ & $\begin{array}{l}2,39 \pm \\
1,30^{*}\end{array}$ & $\begin{array}{c}1,91 \pm \\
1,04\end{array}$ & $\begin{array}{l}4,86 \pm \\
3,40^{*}\end{array}$ & $\begin{array}{l}4,80 \pm \\
3,38^{*}\end{array}$ & $\begin{array}{l}4,79 \pm \\
3,41^{*}\end{array}$ & $\begin{array}{l}4,88 \pm \\
3,40^{*}\end{array}$ & $\begin{array}{l}3,60 \pm \\
2,46^{*}\end{array}$ \\
\hline
\end{tabular}

Примітки: * - статистично достовірна різниця Р <0,05 відносно контролю норми; ${ }^{\circ}$ - дані, отримані для однієї тварини

Наступне висівання проводили на десяту добу після інфікування. Встановили зменшення частоти виявлення мікроаерофільних Lactobacillus на 20,6\% порівняно з показниками першої доби дисбіозу. Зміни частоти виявлення інших мікроорганізмів коливалися у межах 1,0-5,9\%. Також дослідили кількісні зміни складу мікрофлори піхви мишей. Кількість мікроаерофільних лактобацил знизилася до 1,07 $\pm 0,58 \mathrm{lgKУО/мл,} \mathrm{анае-}$ робних лактобацил до $3,60 \pm 2,46 \lg \mathrm{УО} /$ мл, у той час як кількість стафілококів зросла до $3,36 \pm 2,36 \operatorname{lgKУО/мл.~Відношення~}$ кількості аеробів до анаеробів також змінилося та склало 1 : 83. Загальне мікробне число зросло до $2,79 \times 10^{5} \mathrm{KУO} /$ мл за рахунок збільшення кількості анаеробних бактерій.

На десяту добу встановили певний баланс у складі мікрофлори піхви: кількість мікроорганізмів коливалася в межах статистичної похибки. Встановили суттєве збільшення кількості представників умовно-патогенної флори, зокрема стафілококів та ентеробактерій, що свідчить про їх домінування серед аеробних і факультативно-анаеробних бактерій у складі мікрофлори піхви. У той же час відбувалося зниження кількості як мікроаерофільних, так і анаеробних Lactobacillus, що поряд зі збільшенням кількості анаеробних мікроорганізмів, які колонізують піхву мишей, і спричинило значний зсув відношення кількості аеробів до анаеробів до значень, характерних для дисбіозу.

Для визначення ефективності корекції дисбіозу репродуктивного тракту проведено низку експериментів зі впливу лікувальних препартів бактеріофагів як окремо, так і в комбінації 3 пробіотичним препаратом «Вагілак». Висівання вагінального вмісту проводили через 24 год., 10 та 20 діб після останнього 
введення препаратів. Вивчаючи вплив бактеріофага стафілококового рідкого на стан мікрофлори піхви мишей за дисбіозі, виявили значне зменшення кількості стафілококів - у 22,5 раза через добу після останнього введення препарату $(2,00 \pm 1,16 \operatorname{lgKУО/мл)~}$

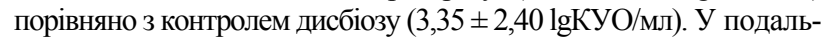
шому кількість стафілококів дещо зросла в межах статистичної похибки. Зміни кількості інших мікроорганізмів були незначними. Частота виявлення всіх досліджуваних бактерій залишилася незмінною. Загальне мікробне число при цьому зменшувалося $32,80 \times 10^{5}$ до $2,75 \times 10^{5} \mathrm{KУО/мл} \mathrm{через} 24$ год. після останнього введення препарату, до 2,72 × $10^{5}$ КУО/мл через 10 діб та до $2,69 \times 10^{5}$ КУО/мл через 20 діб. Співвідношення кількості аеробів : анаеробів становило $1: 242,1: 240$ та $1: 233$ відповідно порівняно $з$ показником дисбіозу $1: 85$.

Під час вивчення впливу інтесті-бактеріофага рідкого відмічено зменшення кількості стафілококів у 24,5 раза через 24 год. після останнього введення препарату. Надалі кількість стафілококів продовжувала повільно знижуватися. Кількість ентерококів також зменшилася у 1,3 раза та зменшувалася i далі, причому, починаючи 3 десятої доби після останнього введення препарату, знизилася також і частота їх виявлення на $6,7 \%$. Частота виявлення ентеробактерій знизилася до $10,0 \%$ порівняно $з$ показником дисбіозу 20,0\%. При цьому зменшилася їх кількість у 7,8 раза та продовжувала повільно зменшуватися на 10- та 20-ту добу. Загальне мікробне число зменшилося до $2,72 \times 10^{5} \mathrm{KУО/мл} \mathrm{через} 24$ год. після останнього введення препарату, 2,70 × $10^{5}$ КУО/мл через 10 діб та до 2,68 × $10^{5}$ КУО/мл через 20 діб. Співвідношення кількості аеробів : анаеробів становило $1: 310,1: 318$ та $1: 322$ відповідно.

Застосування піобактеріофага викликало зменшення кількості стафілококів у 24,2 раза через 24 год. після останнього введення препарату, надалі їх кількість продовжувала зменшуватися. Кількість стрептококів знизилися в 1,2 раза порівняно 3 контролем дисбіозу до показників норми та на 20-ту добу складала $2,59 \pm 1,40 \operatorname{lgKУО/мл.~Кількість~ентерококів~також~знизи-~}$ лася у 1,3 раза через добу після останнього введення препарату та продовжувала знижуватися далі. Частота їх виявлення знизилася на 6,7\%. Через 24 год. знизилася також кількість ентеробактерій (у 3,4 раза) та продовжувала знижуватися далі (у 5,9 раза на 20-ту добу після останнього введення препарату). Частота виявлення ентеробактерій також зменшилася на 8,9\%. Загальне мікробне число зменшилося до $2,73 \times 10^{5}$ КУО/мл через 24 год. після останнього введення препарату, 2,67 × $10^{5}$ КУО/мЛ через 10 діб і до $2,63 \times 10^{5}$ КУО/мл через 20 діб. Співвідношення кількості аеробів до анаеробів становило $1: 314,1: 316$ та $1: 324$ відповідно.

У наших дослідженнях підтверджено, що самостійне використання антибактеріальних засобів (бактеріофагів) не забезпечує повного відновлення стану вагінальної мікрофлори до нормальних показників, що зазначають також інші автори (Car'kova, 2014; Malanchuk et al., 2016). Відбувається лише зменшення кількості тих умовно-патогенних бактерій, фаги проти яких входили до складу використаних препаратів.

Невід'ємна частина успішної терапії - заключний етап лікування - відновлення мікроекології піхви із застосуванням вагінальних пробіотиків. Лікування дисбіотичних порушень обов'язково повинне включати лікарські засоби, що коригують як кількісний, так і якісний склад мікрофлори, тобто препарати пробіотичної дії (Ling et al., 2013).

Визначаючи вплив на змодельований дисбіоз вагілаку, спостерігали значне збільшення кількості як мікроаерофільних, так і анаеробних лактобацил. Через 24 год. після останнього введення препарату їх кількість зросла у 7,1 та 2,3 раза відповідно, на 10- та 20-ту добу їх кількість продовжувала збільшуватися. При цьому також збільшилася частота їх виділення до 88,9\% для мікроаерофільних лактобацил і до 66,7\% для анаеробних на 20-ту добу після останнього введення препарату. Крім того, визначали зменшення кількості стафілококів у 3,6 раза через 24 год. і подальше зменшення у 7,5 раза на 20-ту добу після останнього введення препарату. Кількість ентерококів зменшувалася в 1,1 раза, бацил - у 4,0, ентеробактерій - у 2,8 , фузобактерій - у 3,6, пептококів - у 1,7, пептострептококів у 2,6, а бактероїдів - у 6,8 раза. На 10- та 20-ту добу після останнього введення препарату їх кількість продовжувала поступово зменшуватися. Також спостерігали зменшення частоти виявлення ентерококів на 6,7\% на 20-ту добу, мікрококів - на $18,9 \%$ через 24 год, бацил - на 18,9\%, ентеробактерій - на 8,9\% через 10 діб. Слід зазначити, що кількість і частота вивлення стрептококів і бацил максимально наблизилися до показників норми. Загальне мікробне число зменшилося до 1,02 × $10^{5} \mathrm{KУО/мл}$ через 24 год. після останнього введення препарату, 8,25 $\times 10^{4}$ через 10 діб і до 6,80 × $10^{4}$ КУО/мл через 20 діб. Співвідношення кількості аеробів до анаеробів становило $1: 68,1: 62$ та $1: 63$ відповідно.

Тобто під час використання лише пробіотичного препарату за 20 діб експерименту також не відбулося повного відновлення стану мікрофлори до показників норми. Це свідчить про недоцільність їх окремого використання для корекції дисбіотичних станів репродуктивного тракту.

Корекцію будь-яких інфекційних процесів нижнього відділу статевих шляхів необхідно розглядати 3 позицій вчення про біоценози. Саме тому в лікуванні дисбіотичних порушень репродуктивного тракту важливий комплексний підхід, що включає наявність двох етапів (Ling et al., 2013) - після елімінації специфічного збудника необхідне відновлення біоценозу піхви. Тільки такий інтегрований підхід забезпечує ефективність лікування та запобігає рецидивам запального процесу. На першому етапі за допомогою системних та місцевих антибактеріальних препаратів проводиться санація, мета якої - елімінація строгих анаеробних умовно-патогенних бактерій. Незважаючи на високу ефективність такої терапії, у 30-40\% випадків відмічається розвиток рецидивів бактеріального вагінозу. Потім на другому етапі проводиться відновлення нормальної мікрофлори піхви. Традиційна схема лікування дозволяє швидко усунути симптоми дисбіозу, тому що антибактеріальні препарати пригнічують патогенну та умовно-патогенну флору. Однак дисбіотичні прояви при цьому посилюються, оскільки одночасно відбувається пригнічення пулу лактобацил, що зумовлює потенціювання загальних процесів дисбактеріозу (рецидиву) (Aguin et al., 2014).

Використання комбінації препаратів бактеріофагів та пробіотичного препарату «Вагілак» для корекції дисбіозів показало як безпоседнє знищення умовно-патогенної мікрофлори за рахунок дії фага, так і відновлення кількості інших представників мікрофлори піхви до показників норми за рахунок антагоністичної дії лактобацил.

Комбіноване застосування бактеріофага стафілококового рідкого та вагілаку зумовило суттєве збільшення кількості та частоти виявлення мікроаерофільних і анаеробних лактобацил. Через 24 год. після останнього введення препаратів кількість їх зросла у 20,8 та 2,1 раза відповідно, а на 10 - та 20-ту добу продовжувала зростати (табл. 2). Частота виділення мікроаерофільних лактобацил зросла до $100 \%$ через добу після останнього введення препаратів, а анаеробних - до 70\% на 20-ту добу, що відповідає показникам нормофлори вагінального біотопу. Також визначено зменшення кількості стафілококів, стрептококів, ентерококів, бацил і ентеробактерій у $30,1,1,1,1,5,2,2$ та 11,8 раза відповідно через добу після останнього введення препаратів. Надалі на 10- та 20-ту добу продовжувала знижуватися кількість ентерококів, бацил і ентеробактерій, максимально наближаючись до показників норми. Показники інших представників вагінальної мікрофлори коливалися в межах статистичної похибки. Також через 24 год. після останнього введення препаратів спостерігалося зменшення частоти виявлення ентерококів, мікрококів і ентеробактерій на $10 \%$, а бацил - на $20 \%$ порівняно $з$ контролем дисбіозу.

Кількість анаеробних бактерій також зазнала значних змін. Кількість фузобактерій зменшилася у 33,2 раза через 24 год. після останнього введення препаратів, пептококів - у 2,3 раза, 
пептострептококів - у 6,6 раза, а бактероїдів - у 7,9 раза, що практично відповідало показникам норми. На 10- та 20-ту добу продовжилося поступове зменшення кількості цих бактерій порівняно з контролем дисбіозу. Також спостерігали зменшення частоти виявлення пептострептококів на $10 \%$.

При цьому загальне мікробне число зменшилося до 5,81 × $10^{4}$ КУО/мл через 24 год. після останнього введення препаратів, до $5,25 \times 10^{4}$ через 10 діб та до $4,77 \times 10^{4} \mathrm{KУО/мл} \mathrm{через} 20$ діб, що наближувалося до показника норми (4,69 × 104 КУО/мл). Співвідношення кількості аеробів до анаеробів також зсувалося у бік норми та становило $1: 59,1: 57$ та $1: 52$ відповідно порівняно 3 контролем норми $(1: 52)$.

Інтесті-бактеріофаг рідкий у комплексі з вагілаком також викликав зміни кількісних показників складу мікрофлори за дисбіозу до показників норми. Кількість мікроаерофільних і анаеробних лактобацил зросла через 24 год. після останнього введення препаратів у 16,6 та 2,2 раза відповідно порівняно 3 показником дисбіозу, а на 10- та 20-ту добу їх кількість продовжувала збільшуватися (табл. 3). Також зросла частота їх виділення. Через добу частота виявлення мікроаерофільних лактобацил сягнула свого максимуму (100\%). На цьому етапі частота вивлення анаеробних лактобацил зросла на $20 \%$, а на 20 -ту добу - на 26,7\% порівняно з контролем дисбіозу.

Кількість інших бактерій (як аеробних і факультативноанаеробних, так і анаеробних) значно знизилася. Через добу після останнього введення препаратів кількість стафілококів зменшилася у 25,9 раза, кількість стрептококів і гарднерел - у 1,1, ентерококів - у 1,5, бацил - у 3,3, ентеробактерій - у 7,8 раза, тоді як кількість мікрококів зросла в 1,3 раза. У подальшому на 10- та 20-ту добу спостерігали поступове зменшення кількості вказаних бактерій. Що стосується частоти виявлення цих мікроорганізмів у складі вагінальної мікрофлори, встановили зменшення ентерококів і ентеробактерій на $10 \%$, хоча на 20 -ту добу для ентеробактерій цей показник відновився до рівня дисбіозу.

\section{Таблиця 2}

Мікрофлора піхви під час корекції дисбіозу, викликаного введенням плівкотвірного штаму S. aureus, за допомогою бактеріофага стафілококового рідкого окремо та у комплексі з вагілаком через 20 діб після їх уведення $(\operatorname{lgKУO} / \mathrm{Mл}, \mathrm{x} \pm \mathrm{SD})$

\begin{tabular}{|c|c|c|c|c|c|c|c|c|c|c|c|c|c|}
\hline \multirow[b]{3}{*}{ Групи тварин } & \multicolumn{13}{|c|}{ Мікроорганізми } \\
\hline & \multirow[b]{2}{*}{ 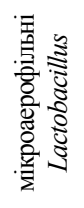 } & \multicolumn{7}{|c|}{ факультативно-анаеробні та аеробні мікроорганізми } & \multicolumn{5}{|c|}{ анаеробні мікроорганізми } \\
\hline & & 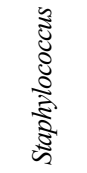 & 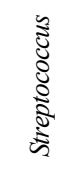 & 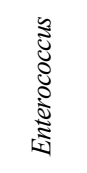 & 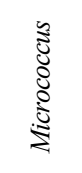 & 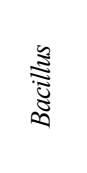 & 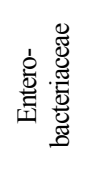 & 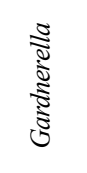 & 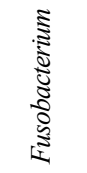 & 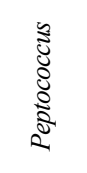 & 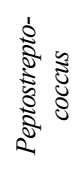 & 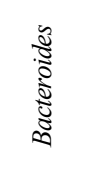 & 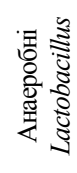 \\
\hline $\begin{array}{l}\text { Контроль норми, } \\
\mathrm{n}=10\end{array}$ & $\begin{array}{c}2,29 \pm \\
1,46\end{array}$ & $\begin{array}{c}1,85 \pm \\
1,17\end{array}$ & $\begin{array}{c}2,60 \pm \\
1,28\end{array}$ & $\begin{array}{c}1,80 \pm \\
1,18\end{array}$ & $1,78^{\circ}$ & $1,00^{\circ}$ & $1,30^{\circ}$ & $\begin{array}{c}1,82 \pm \\
1,18\end{array}$ & $\begin{array}{c}3,16 \pm \\
2,38\end{array}$ & $\begin{array}{c}4,09 \pm \\
3,30\end{array}$ & $\begin{array}{c}3,90 \pm \\
2,53\end{array}$ & $\begin{array}{c}3,71 \pm \\
2,45\end{array}$ & $\begin{array}{c}4,28 \pm \\
3,34\end{array}$ \\
\hline $\begin{array}{l}\text { Контроль дисбіозу, } \\
\mathrm{n}=10\end{array}$ & 1,00 & $\begin{array}{c}3,35 \pm \\
2,40\end{array}$ & $\begin{array}{c}2,66 \pm \\
1,49\end{array}$ & $\begin{array}{c}2,03 \pm \\
1,28\end{array}$ & $\begin{array}{c}1,73 \pm \\
1,18\end{array}$ & $\begin{array}{c}1,82 \pm \\
0,76\end{array}$ & $\begin{array}{c}2,37 \pm \\
1,54\end{array}$ & $\begin{array}{c}1,92 \pm \\
0,76\end{array}$ & $\begin{array}{c}4,86 \pm \\
3,48\end{array}$ & $\begin{array}{c}4,80 \pm \\
3,36\end{array}$ & $\begin{array}{c}4,79 \pm \\
3,46\end{array}$ & $\begin{array}{c}4,88 \pm \\
3,36\end{array}$ & $\begin{array}{c}3,62 \pm \\
2,54\end{array}$ \\
\hline $\begin{array}{l}\text { Бактеріофаг стафілококовий } \\
\text { рідкий, } \mathrm{n}=9\end{array}$ & $\begin{array}{l}1,45 \pm \\
0,92 *\end{array}$ & $\begin{array}{l}2,01 \pm \\
1,21^{*}\end{array}$ & $\begin{array}{c}2,64 \pm \\
1,41\end{array}$ & $\begin{array}{c}2,04 \pm \\
1,23\end{array}$ & $\begin{array}{c}1,74 \pm \\
0,85\end{array}$ & $\begin{array}{c}1,81 \pm \\
0,85\end{array}$ & $2,41^{\circ}$ & $\begin{array}{c}1,94 \pm \\
1,18\end{array}$ & $\begin{array}{c}4,85 \pm \\
3,30\end{array}$ & $\begin{array}{c}4,78 \pm \\
3,26\end{array}$ & $\begin{array}{c}4,77 \pm \\
3,30\end{array}$ & $\begin{array}{c}4,87 \pm \\
3,43\end{array}$ & $\begin{array}{c}3,63 \pm \\
2,46\end{array}$ \\
\hline $\begin{array}{l}\text { Вагілак, } \\
\mathrm{n}=9\end{array}$ & $\begin{array}{l}1,96 \pm \\
1,26^{*}\end{array}$ & $\begin{array}{l}2,47 \pm \\
1,66^{*}\end{array}$ & $\begin{array}{c}2,60 \pm \\
1,54\end{array}$ & $\begin{array}{c}1,92 \pm \\
1,18\end{array}$ & $1,78^{\circ}$ & $1,00^{\circ}$ & $1,78^{\circ}$ & $\begin{array}{c}1,88 \pm \\
0,85\end{array}$ & $\begin{array}{l}3,99 \pm \\
2,61^{*}\end{array}$ & $\begin{array}{c}4,44 \pm \\
3,49\end{array}$ & $\begin{array}{l}3,98 \pm \\
2,62^{*}\end{array}$ & $\begin{array}{l}3,93 \pm \\
2,62 *\end{array}$ & $\begin{array}{c}4,05 \pm \\
3,48\end{array}$ \\
\hline $\begin{array}{l}\text { Бактеріофаг стафілококовий } \\
\text { рідкий + вагілак, } \mathrm{n}=10\end{array}$ & $\begin{array}{c}2,29 \pm \\
1,46^{*}\end{array}$ & $\begin{array}{l}1,88 \pm \\
1,03^{*}\end{array}$ & $\begin{array}{c}2,60 \pm \\
1,46\end{array}$ & $\begin{array}{c}1,81 \pm \\
0,85\end{array}$ & $1,85^{\circ}$ & $1,00^{\circ}$ & $1,00^{\circ}$ & $\begin{array}{c}1,88 \pm \\
0,85\end{array}$ & $\begin{array}{l}3,20 \pm \\
2,41^{*}\end{array}$ & $\begin{array}{l}4,10 \pm \\
3,34^{*}\end{array}$ & $\begin{array}{l}3,90 \pm \\
2,41^{*}\end{array}$ & $\begin{array}{l}3,77 \pm \\
2,48^{*}\end{array}$ & $\begin{array}{r}4,27 \pm \\
3,49 *\end{array}$ \\
\hline
\end{tabular}

Примітки: див. табл. 1.

\section{Таблиця 3}

Мікрофлора піхви під час корекції дисбіозу, викликаного введенням плівкотвірного штаму S. aureus, за допомогою інтесті-бактеріофага рідкого окремо та в комплексі з вагілаком через 20 діб після їх уведення (lgKУO/мл, х \pm SD)

\begin{tabular}{|c|c|c|c|c|c|c|c|c|c|c|c|c|c|}
\hline \multirow[b]{3}{*}{ Групи тварин } & \multicolumn{13}{|c|}{ Мікроорганізми } \\
\hline & \multirow[b]{2}{*}{ 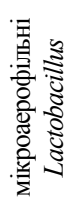 } & \multicolumn{7}{|c|}{ факультативно-анаеробні та аеробні мікроорганізми } & \multicolumn{5}{|c|}{ анаеробні мікроорганізми } \\
\hline & & 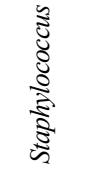 & 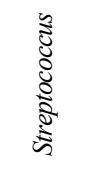 & 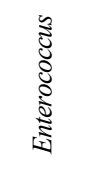 & 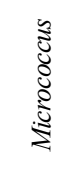 & 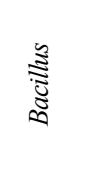 & 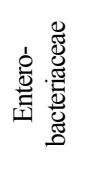 & 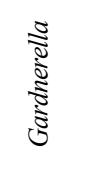 & 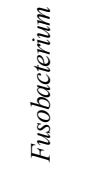 & 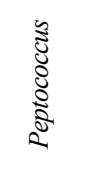 & 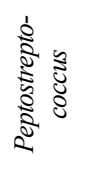 & 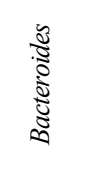 & 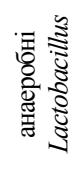 \\
\hline $\begin{array}{l}\text { Контроль норми, } \\
\mathrm{n}=10\end{array}$ & $\begin{array}{c}2,29 \pm \\
1,46\end{array}$ & $\begin{array}{c}1,85 \pm \\
1,17\end{array}$ & $\begin{array}{c}2,60 \pm \\
1,28\end{array}$ & $\begin{array}{c}1,80 \pm \\
1,18\end{array}$ & $1,78^{\circ}$ & $1,00^{\circ}$ & $1,30^{\circ}$ & $\begin{array}{c}1,82 \pm \\
1,18\end{array}$ & $\begin{array}{c}3,16 \pm \\
2,38\end{array}$ & $\begin{array}{c}, 09 \pm \\
3,30\end{array}$ & $\begin{array}{c}3,90 \pm \\
2,53\end{array}$ & $\begin{array}{c}3,71 \pm \\
2,45\end{array}$ & $\begin{array}{c}4,28 \pm \\
3,34\end{array}$ \\
\hline $\begin{array}{l}\text { Контроль дисбіозу, } \\
\mathrm{n}=10\end{array}$ & 1,00 & $\begin{array}{c}3,35 \pm \\
2,40\end{array}$ & $\begin{array}{c}2,66 \pm \\
1,49\end{array}$ & $\begin{array}{c}2,03 \pm \\
1,28\end{array}$ & $\begin{array}{c}1,73 \pm \\
1,18\end{array}$ & $\begin{array}{c}1,82 \pm \\
0,76\end{array}$ & $\begin{array}{c}2,37 \pm \\
1,54\end{array}$ & $\begin{array}{c}1,92 \pm \\
0,76\end{array}$ & $\begin{array}{c}4,86 \pm \\
3,48\end{array}$ & $\begin{array}{c}4,80 \pm \\
3,36\end{array}$ & $\begin{array}{c}4,79 \pm \\
3,46\end{array}$ & $\begin{array}{c}4,88 \pm \\
3,36\end{array}$ & $\begin{array}{c}3,62 \pm \\
2,54\end{array}$ \\
\hline $\begin{array}{l}\text { Інтесті-бактеріофаг рідкий, } \\
\text { n =9 }\end{array}$ & $\begin{array}{l}1,40 \pm \\
0,76^{*}\end{array}$ & $\begin{array}{l}1,93 \pm \\
1,12^{*}\end{array}$ & $\begin{array}{c}2,65 \pm \\
1,48\end{array}$ & $\begin{array}{c}1,87 \pm \\
0,76\end{array}$ & $\begin{array}{c}1,74 \pm \\
0,85\end{array}$ & $\begin{array}{c}1,73 \pm \\
0,76\end{array}$ & $1,30^{\circ}$ & $\begin{array}{c}1,86 \pm \\
0,85\end{array}$ & $\begin{array}{c}4,85 \pm \\
3,45\end{array}$ & $\begin{array}{c}4,79 \pm \\
3,34\end{array}$ & $\begin{array}{c}4,77 \pm \\
3,28\end{array}$ & $\begin{array}{c}4,86 \pm \\
3,40\end{array}$ & $\begin{array}{c}3,62 \pm \\
2,41\end{array}$ \\
\hline $\begin{array}{l}\text { Вагілак, } \\
\mathrm{n}=9\end{array}$ & $\begin{array}{l}1,96 \pm \\
1,26^{*}\end{array}$ & $\begin{array}{l}2,47 \pm \\
1,66^{*}\end{array}$ & $\begin{array}{c}2,60 \pm \\
1,54\end{array}$ & $\begin{array}{c}1,92 \pm \\
1,18\end{array}$ & $1,78^{\circ}$ & $1,00^{\circ}$ & $1,78^{\circ}$ & $\begin{array}{c}1,88 \pm \\
0,85\end{array}$ & $\begin{array}{l}3,99 \pm \\
2,61^{*}\end{array}$ & $\begin{array}{c}4,44 \pm \\
3,49\end{array}$ & $\begin{array}{l}3,98 \pm \\
2,62^{*}\end{array}$ & $\begin{array}{l}3,93 \pm \\
2,62 *\end{array}$ & $\begin{array}{c}4,05 \pm \\
3,48\end{array}$ \\
\hline $\begin{array}{l}\text { Інтесті-бактеріофаг рідкий + } \\
\text { вагілак, } \mathrm{n}=9\end{array}$ & $\begin{array}{l}2,26 \pm \\
1,41^{*}\end{array}$ & $\begin{array}{l}1,88 \pm \\
1,26^{*}\end{array}$ & $\begin{array}{c}2,60 \pm \\
1,49\end{array}$ & $\begin{array}{c}1,82 \pm \\
1,18\end{array}$ & $1,78^{\circ}$ & $1,00^{\circ}$ & $1,00^{\circ}$ & $\begin{array}{c}1,87 \pm \\
1,18\end{array}$ & $\begin{array}{l}3,23 \pm \\
2,40^{*}\end{array}$ & $\begin{array}{l}4,14 \pm \\
3,41^{*}\end{array}$ & $\begin{array}{l}3,90 \pm \\
2,46^{*}\end{array}$ & $\begin{array}{l}3,71 \pm \\
2,48^{*}\end{array}$ & $\begin{array}{l}4,28 \pm \\
3,45^{*}\end{array}$ \\
\hline
\end{tabular}

Примітка: див. табл. 1.

Кількість фузобактерій через 24 год. після останнього введення препаратів зменшилася у 30,4 , пептококів - у 2,0, пептострептококів - у 6,81, а бактероїдів - у 9,3 раза. Надалі тривало зменшення кількості цих бактерій практично до показників норми. Також визначали зменшення частоти виявлення пептоковів на $10 \%$ через 24 год. після останнього введення препаратів та на $20 \%$ - на 10 - та 20 -ту добу.

При цьому загальне мікробне число зменшилося до 6,06 × $10^{4}$ КУО/мл через 24 год. після останнього введення препарату, до 5,64 × $10^{4}$ КУО/мл через 10 діб та до 4,85 × $10^{4}$ КУО/мл через 20 діб, що наближалося до показника норми $\left(4,69 \times 10^{4} \mathrm{KУО/мл).}\right.$ Співвідношення кількості аеробів до анаеробів становило $1: 64$, $1: 61$ та $1: 54$ відповідно порівняно з контролем норми $(1: 52)$.

Під час застосування піобактеріофага полівалентного та вагілаку спостерігали збільшення кількості мікроаерофільних і анаеробних лактобацил у 20,3 та 2,3 раза відповідно через добу після останнього введення препаратів. У подальшому на 10- та 20-ту добу спостерігали поступове збільшення кількості ана- 
еробних лактобацил і незначне зменшення мікроаерофільних (табл. 4). При цьому частота виділення зросла в обох випадках і на 20 -ту добу становила $100 \%$ для мікроаерофільних лактобацил і $70 \%$ для анаеробних.

Визначено зменшення кількості стафілококів, стрептококів, ентерококів, бацил, ентеробактерій та гарднерел: у 28,2, $1,1,1,4,3,3,23,5$ та 1,1 раза відповідно через 24 год. після останнього введення препаратів. У подальшому кількість їх продовжувала поступово знижуватися порівняно з контролем дисбіозу. Кількість анаеробних бактерій також знизилася. Кількість фузобактерій зменшилася у 13,2 раза через добу після останнього введення препаратів, пептококів - у 2,0, пепто- стрептококів - у 6,6, а бактероїдів - у 10,7 раза, що відповідало показникам норми. Ці показники продовжували знижуватися на 10 - та 20-ту добу. Також спостерігали зменшення частоти виявлення ентерококів і ентеробактерій на $10 \%$, мікрококів і бацил - на $20 \%$ через 24 год., а пептострептококів - на $10 \%$ через 10 діб після останнього введення препаратів.

При цьому загальне мікробне число становило $6,33 \times$ $10^{4} \mathrm{KУО/мл} \mathrm{через} 24$ год. після останнього введення препаратів, 5,61 × $10^{4}$ через 10 діб, 4,85 × $10^{4} \mathrm{KУО/мл} \mathrm{через} 20$ діб порівняно $з$ показником нормофлори $\left(4,69 \times 10^{4}\right.$ КУО/мл). Співвідношення аероби : анаероби становило $1: 67,1: 62$ та $1: 55$ відповідно порівняно з контролем норми $(1: 52)$.

\section{Таблиця 4}

Мікрофлора піхви під час корекції дисбіозу, викликаного введенням плівкотвірного штаму $S$. aureus, за допомогою піобактеріофага полівалентного окремо та у комплексі з вагілаком через 20 діб після їх уведення (lgKУО/мл, $\mathrm{x} \pm \mathrm{SD})$

\begin{tabular}{|c|c|c|c|c|c|c|c|c|c|c|c|c|c|}
\hline \multirow[b]{3}{*}{ Групи тварин } & \multicolumn{13}{|c|}{ Мікроорганізми } \\
\hline & \multirow[b]{2}{*}{ 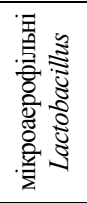 } & \multicolumn{7}{|c|}{ факультативно-анаеробні та аеробні мікроорганізми } & \multicolumn{5}{|c|}{ анаеробні мікроорганізми } \\
\hline & & 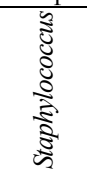 & 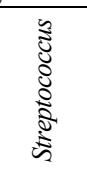 & 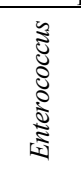 & 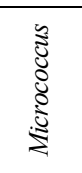 & 胥 & 惫 & 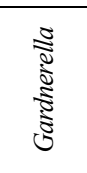 & 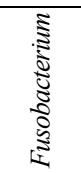 & 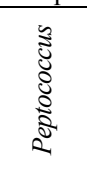 & 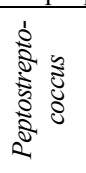 & 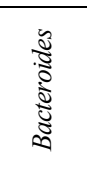 & 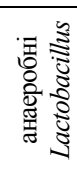 \\
\hline $\begin{array}{l}\text { Контроль норми, } \\
\mathrm{n}=10\end{array}$ & $\begin{array}{c}2,29 \pm \\
1,46\end{array}$ & $\begin{array}{c}1,85 \pm \\
1,17\end{array}$ & $\begin{array}{c}2,60 \pm \\
1,28\end{array}$ & $\begin{array}{c}1,80 \pm \\
1,18\end{array}$ & $1,78^{\circ}$ & $1,00^{\circ}$ & $1,30^{\circ}$ & $\begin{array}{c}1,82 \pm \\
1,18\end{array}$ & $\begin{array}{c}3,16 \pm \\
2,38\end{array}$ & $\begin{array}{c}4,09 \pm \\
3,30\end{array}$ & $\begin{array}{c}3,90 \pm \\
2,53\end{array}$ & $\begin{array}{c}3,71 \pm \\
2,45\end{array}$ & $\begin{array}{c}4,28 \pm \\
3,34\end{array}$ \\
\hline $\begin{array}{l}\text { Контроль дисбіозу, } \\
\mathrm{n}=10\end{array}$ & 1,00 & $\begin{array}{c}3,35 \pm \\
2,40\end{array}$ & $\begin{array}{c}2,66 \pm \\
1,49\end{array}$ & $\begin{array}{c}2,03 \pm \\
1,28\end{array}$ & $\begin{array}{c}1,73 \pm \\
1,18\end{array}$ & $\begin{array}{c}1,82 \pm \\
0,76\end{array}$ & $\begin{array}{c}2,37 \pm \\
1,54\end{array}$ & $\begin{array}{c}1,92 \pm \\
0,76\end{array}$ & $\begin{array}{c}4,86 \pm \\
3,48\end{array}$ & $\begin{array}{c}4,80 \pm \\
3,36\end{array}$ & $\begin{array}{c}4,79 \pm \\
3,46\end{array}$ & $\begin{array}{c}4,88 \pm \\
3,36\end{array}$ & $\begin{array}{c}3,62 \pm \\
2,54\end{array}$ \\
\hline $\begin{array}{l}\text { Піобактеріофаг полівалентний, } \\
\mathrm{n}=9\end{array}$ & $\begin{array}{l}1,38 \pm \\
0,74^{*}\end{array}$ & $\begin{array}{l}1,91 \pm \\
1,04^{*}\end{array}$ & $\begin{array}{c}2,59 \pm \\
1,40\end{array}$ & $\begin{array}{c}1,87 \pm \\
1,06\end{array}$ & $\begin{array}{c}1,81 \pm \\
0,85\end{array}$ & $\begin{array}{c}1,78 \pm \\
1,15\end{array}$ & $1,60^{\circ}$ & $\begin{array}{c}1,88 \pm \\
0,85\end{array}$ & $\begin{array}{c}4,84 \pm \\
3,51\end{array}$ & $\begin{array}{c}4,78 \pm \\
3,52\end{array}$ & $\begin{array}{c}4,76 \pm \\
3,52\end{array}$ & $\begin{array}{c}4,86 \pm \\
3,48\end{array}$ & $\begin{array}{c}3,64 \pm \\
2,48\end{array}$ \\
\hline $\begin{array}{l}\text { Вагілак, } \\
\mathrm{n}=9\end{array}$ & $\begin{array}{l}1,96 \pm \\
1,26^{*}\end{array}$ & $\begin{array}{l}2,47 \pm \\
1,66^{*}\end{array}$ & $\begin{array}{c}2,60 \pm \\
1,54\end{array}$ & $\begin{array}{c}1,92 \pm \\
1,18\end{array}$ & $1,78^{\circ}$ & $1,00^{\circ}$ & $1,78^{\circ}$ & $\begin{array}{c}1,88 \pm \\
0,85\end{array}$ & $\begin{array}{l}3,99 \pm \\
2,61^{*}\end{array}$ & $\begin{array}{c}4,44 \pm \\
3,49\end{array}$ & $\begin{array}{l}3,98 \pm \\
2,62 *\end{array}$ & $\begin{array}{l}3,93 \pm \\
2,62 *\end{array}$ & $\begin{array}{c}4,05 \pm \\
3,48\end{array}$ \\
\hline $\begin{array}{l}\text { Піобактеріофаг полівалентний + } \\
\text { вагілак, n = } 10\end{array}$ & $\begin{array}{l}2,26 \pm \\
1,38^{*}\end{array}$ & $\begin{array}{l}1,88 \pm \\
1,16^{*}\end{array}$ & $\begin{array}{c}2,59 \pm \\
1,51\end{array}$ & $\begin{array}{c}1,82 \pm \\
0,76\end{array}$ & $1,78^{\circ}$ & $1,00^{\circ} *$ & $1,00^{\circ} *$ & $\begin{array}{c}1,87 \pm \\
1,06\end{array}$ & $\begin{array}{l}3,26 \pm \\
2,43^{*}\end{array}$ & $\begin{array}{l}4,16 \pm \\
3,43^{*}\end{array}$ & $\begin{array}{l}3,91 \pm \\
2,48^{*}\end{array}$ & $\begin{array}{l}3,73 \pm \\
2,51^{*}\end{array}$ & $\begin{array}{l}4,25 \pm \\
3,43^{*}\end{array}$ \\
\hline
\end{tabular}

Примітка: див. табл. 1.

\section{Обговорення}

Наведені дані свідчать про практично повне відновлення показників мікрофлори вагінального біотопу за комбінованого використання будь-якого з обраних препаратів бактеріофагів та пробіотика «Вагілак». Літературні дані щодо порівняння різних схем корекції вагінального дисбіозу визначили, що повного знищення умовно-патогенної мікрофлори не відбулося ні за однієї схеми корекції дисбіозу.

У дослідженнях Nazarenko and Solov'eva (2013) під час застосування орального пробіотика «Вагісан» на основі лактобацил (Lactobacillus rhamnosus GR-1 та L. reuteri RC-14 у дозі $10^{9} \mathrm{KУO)} \mathrm{знищення} \mathrm{умовно-патогенної} \mathrm{мікрофлори} \mathrm{спостері-}$ гали у 87,5\% жінок, за двоетапного лікування метронідазолом і одним із кислототвірних еубіотиків (біопрепарати лактобактерин, біфідумбактерин у супозиторіях) - у 85,0\%, а за монотерапії метронідазолом - у 70,0\%. Причому за схем корекції дисбіозу вагінального тракту, застосовуваних у другій і третій групах, спостерігали велику кількість рецидивів, які виникали в різні терміни після лікування. Фактор розвитку рецидивів дефіцит лакто- та біфідобактерій, що посилюється після завершення курсу антибактеріальної терапії (Heczko et al., 2015). Це пов'язано 3 тим, що терапія антибіотиками, ліквідуючи умовнопатогенні мікроорганізми, часто не створює умов для достатньо швидкого відновлення нормальної мікрофлори піхви.

Один із головних недоліків біотерапевтичних препаратів для корекції мікрофлори піхви - вони містять біфідо- або лактобактерин, виділений у людей із кишківника, тому під час потрапляння в нехарактерну для їх проживання нішу (піхву) ці мікроорганізми, що володіють слабкою адгезивною активністю відносно вагінальних епітеліоцитів, не здатні перебувати там тривалий час. У результаті це лікування може зумовити нестійкий клінічний ефект.

У зв'язку з тим, що застосування антибіотиків для корекції дисбіозу репродуктивного тракту супроводжується рецидивами, доцільно обов'язково проводити другий етап лікування - від- новлення біоценозу піхви. Група вчених (Radzinskij and Ordiyanc, 2012) у 2010-2011 роках провела масштабне дослідження клінічної та мікробіологічної ефективності різних схем лікування бактеріальних вагінальних інфекцій неспецифічної етіології. На першому етапі дослідження пацієнтки отримували антибактеріальну або антисептичну терапію згідно з інструкцією із застосування (деквалінію хлорид - «Флуомізин», тернідазол + неоміцину сульфат + ністатин + преднізолону метасульфобензоат + хлоргексидин + повідон-йод, метронідазол + міконазол або кліндаміцин). На другому етапі жінок поділили на дві групи. Хворим із першої групи проводили лікування препаратом «Генофлор Е». Друга група жінок (група контролю) ніяких засобів для відновлення мікрофлори піхви не отримувала. Після курсу лікування у пацієнток, які отримали двоетапну терапію, зміни біоценозу піхви в цілому були позитивними - у $91,0 \%$ під час обстеження виявлено I-II ступінь чистоти піхви. У жодної із жінок не спостерігали будь-яких небажаних побічних реакцій, пов'язаних із застосуванням лікарського засобу (Radzinskij and Ordiyanc, 2012).

За даними Malanchuk et al. (2016) відновлення нормальної мікрофлори піхви спостерігали у 93,0\% жінок I групи, що отримували пробіотик «Лактостар Плюс» і вагінальні таблетки «Фемінум Інтима», і тільки у 40,0\% жінок II групи, що отримували лише етіотропну терапію. Крім того, рецидиви бактеріального вагінозу визначили у трьох пацієнток II групи, а також у 2,3 раза частіше виявляли грибкову інфекцію. Тобто використання пробіотиків поряд з іншими антибактеріальними засобами, як показано нами, та бактеріофагами зокрема, - обов'язкова складова ефективної терапії дисбіотичних порушень репродуктивного тракту.

\section{Висновки}

Використання препаратів бактеріофагів не показало повного відновлення складу нормофлори вагінального біотопу. Вони лише знищували умовно-патогенні бактерії, проти яких спря- 
мовані, не викликаючи значних змін інших мікроорганізмів. Тому зареєстровано подальший зсув співвідношення кількості аеробів та анаеробів убік дисбіозу, що не можна характеризувати як позитивний вплив препаратів бактеріофагів.

Однак у поєднанні з пробіотиком усі використані бактеріофаги здійснювали практично повне відновлення складу мікрофлори. Найкращий корекційний ефект визначали для комплексу «бактеріофаг стафілококовий рідкий - вагілак», що зумовив максимальне зниження загального мікробного числа до $4,77 \times 10^{4} \mathrm{KУО/мл} \mathrm{і} \mathrm{відновлення} \mathrm{показника} \mathrm{аероби} \mathrm{:} \mathrm{анаероби}$ до $1: 52$ за показників норми 4,69×104 КУО/мл та $1: 52$.

Лікувальні препарати бактеріофагів ефективні для корекції порушень складу мікрофлори, викликаних здатними до утворення біоплівок стафілококами, in vivo, тому доцільне їх використання в медичній практиці як самостійно, так і в комплексі з іншими засобами. Це дозволить значно підвищити ефективність лікування, уникнувши при цьому низки ускладнень і можливості рецидивування.

\section{References}

Abedon, S. T. (2015). Ecology of anti-biofilm agents II: Bacteriophage exploitation and biocontrol of biofilm bacteria. Pharmaceuticals, 8(3), 559-589.

Abedon, S. T. (2016). Bacteriophage exploitation of bacterial biofilms: Phage preference for less mature targets? FEMS Microbiology Letters, 363(3), fnv246.

Aguin, T., Akins, R. A., \& Sobel, J. D. (2014). High-dose vaginal maintenance metronidazole for recurrent bacterial vaginosis: A pilot study. Sexually Transmitted Diseases, 41(5), 290-291.

Algburi, A., Volski, A., \& Chikindas, M. L. (2015). Natural antimicrobials subtilosin and lauramide arginine ethyl ester synergize with conventional antibiotics clindamycin Volski, and metronidazole against biofilms of Gardnerella vaginalis but not against biofilms of healthy vaginal lactobacilli. FEMS Pathogens and Disease, 73(5), ftv018.

Alves, D. R., Gaudion, A., Bean, J. E., Perez Esteban, P., Arnot, T. C., Harper, D. R., Kot, W., Hansen, L. H., Enright, M. C., \& Jenkins, A. T. (2014). Combined use of bacteriophage $\mathrm{K}$ and a novel bacteriophage to reduce Staphylococcus aureus biofilm formation. Applied and Environmental Microbiology, 80(21), 6694-6703.

Berezovskaya, E. S., Makarov, I. O., Gomberg, M. A., Borovkova, E. I., Chulkova, E. A., \& Arakelyan, L. A. (2013). Bioplenki pri bakterial'nom vaginoze [Biofilm formation in the bacterial vaginosis]. Obstetrics, Gynecology and Reproduction, 7(2), 34-36 (in Russian).

Borges, S., Silva, J., \& Teixeira, P. (2014). The role of lactobacilli and probiotics in maintaining vaginal health. Archives of Gynecology and Obstetrics, 289(3), 479-489.

Car'kova, M. A. (2014). Kompleksnoe lechenie i profilaktika recidivov bakterial'nogo vaginoza u zhenshchin reproduktivnogo vozrasta [Multimodal treatment and prevention of recurrent bacterial vaginosis in women of reproductive age]. Medicinskij Sovet, 2, 42-46 (in Russian).

Chan, B. K., \& Abedon, S. T. (2015). Bacteriophages and their enzymes in biofilm control. Current Pharmaceutical Design, 21(1), 85-99.
Deghorain, M., \& Van Melderen, L. (2012). The staphylococci fhages family: An overview. Viruses, 4(12), 3316-3335.

Heczko, P. B., Tomusiak, A., Adamski, P., Jakimiuk, A. J., Stefanski, G., Mikolajczyk-Cichonska, A., Suda-Szczurek, M., \& Strus, M. Supplementation of standard antibiotic therapy with oral probiotics for bacterial vaginosis and aerobic vaginitis: A randomised, double-blind, placebocontrolled trial. BMC Women's Health, 15, e115.

Hoiby, N., Ciofu, O., Johansen, H. K., Song, Z. J., Moser, C., Jensen, P. O., Molin, S., Givskov, M., Tolker-Nielsen, T., \& Bjarnsholt, T. (2011). The clinical impact of bacterial biofilms. International Journal of Oral Science, 3(2), 55-65.

Ling, Z., Liu, X., Chen, W., Luo, Y., Yuan, L., Xia, Y., Nelson, K. E., Huang, S., Zhang, S., Wang, Y., Yuan, J., Li, L., \& Xiang, C. (2013). The restoration of the vaginal microbiota after treatment for bacterial vaginosis with metronidazole or probiotics. Microbial Ecology, 65(3), 773-780.

Lungren, M. P., Christensen, D., Kankotia, R., Falk, I., Paxton, B. E., \& Kim, C. Y. (2013). Bacteriophage K for reduction of Staphylococcus aureus biofilm on central venous catheter material. Bacteriophage, 3(4), e26825.

Machado, A., \& Cerca, N. (2015). Influence of biofilm formation by Gardnerella vaginalis and other anaerobes on bacterial vaginosis. The Journal of Infectious Diseases, 212(12), 1856-1861.

Machado, D., Castro, J., Palmeira-de-Oliveira, A., Martinez-de-Oliveira, J., \& Cerca, N. (2016). Bacterial vaginosis biofilms: Challenges to current therapies and emerging solution. Frontiers in Microbiology, 6, e1528.

Malanchuk, L. M., Malanchuk, S. L., \& Nebeso, T. A. (2016). Vaginalna mikrobiota: Yak vidnoviti balans pri disbiozi [Vaginal microbiota: How to restore balance of the dysbiosis]. Zdorov'e Zhenshchiny, 108, 107-111 (in Ukrainian).

Motlagh, A. M., Bhattacharjee, A. S., \& Goel, R. (2016). Biofilm control with natural and genetically-modified phages. World Journal of Microbiology and Biotechnology, 32(4), e67.

Muzny, C. A., \& Schwebke, J. R. (2015). Biofilms: An underappreciated mechanism of treatment failure and recurrence in vaginal infections. Clinical Infectious Diseases, 61(4), 601-606.

Nazarenko, L. G., \& Solov'eva, N. P. (2013). Primenenie oral'nogo probiotika kak al'ternativnaya klinicheskaya strategiya profilaktiki akusherskih i perinatal'nyh infekcij [The use of oral probiotic as an alternative clinical strategy for the prevention of obstetrical and perinatal infections]. Ukrainian Journal of Dermatology, Venereology, Cosmetology, 51, 147-154 (in Ukrainian).

Radzinskij, V. E., \& Ordiyanc, I. M. (2012). Dvuhehtapnaya terapiya vaginal'nyh infekcij [Two-stage therapy of vaginal infections]. Status Praesens, Moscow (in Russian).

Römling, U., \& Balsalobre, C. (2012). Biofilm infections, their resilience to therapy and innovative treatment strategies. Journal of Internal Medicine, 272(6), 541-561.

Stepanova, N. R., \& Gevorkyan, M. A. (2015). Bakteriofagi: Aspekty primeneniya $\mathrm{v}$ akusherstve $\mathrm{i}$ ginekologii [Bacteriophages: Application in obstetrics and gynecology]. Medicinskij Sovet, 9, 10-14 (in Russian).

Swidsinski, A., Verstraelen, H., Loening-Baucke, V., Swidsinski, S., Mendling, W., \& Halwani, Z. (2013). Presence of a polymicrobial endometrial biofilm in patients with bacterial vaginosis. PLoSOne, 8(1), e53997.

Verstraelen, H., \& Swidsinski, A. (2013). The biofilm in bacterial vaginosis: Implications for epidemiology, diagnosis and treatment. Current Opinion in Infectious Diseases, 26(1), 86-89.

Yilmaz, C., Colak, M., Yilmaz, B. C., Ersoz, G., Kutateladze, M., \& Gozlugol, M. (2013). Bacteriophage therapy in implant-related infections: An experimental study. The Journal of Bone and Joint Surgery, 95(2), 117-125. 